\title{
Experience of radiotherapy in head and neck
}

\section{Experiência da radioterapia em cabeça e pescoço}

\author{
Dhiancarlo Rocha MACEDO' ${ }^{1}$ iD 0000-0002-9241-5187 \\ Anna Claúdia Yokoyama dos ANJOS ${ }^{1}$ iD 0000-0001-6984-4381
}

\begin{abstract}
Objective: The aim of this manuscript was to understand and describe the experience of radiotherapy on the perspective of a woman with oral cancer. Methods: This is a qualitative, exploratory, descriptive study, with theoretical reference of medical anthropology and instrumental case study methodology. Data collection was performed in the oncology sector of a public university hospital in the Southeast region of Brazil, State of Minas Gerais, Brazil and at the participant's residence, during from March to August, 2016. The case selected was of a female patient, diagnosed with Spinocellular Carcinoma in oral cavity, submitted to radiotherapy. Five semi-structured interviews and participant observation were performed and audio-taped. Results: Three thematic units are presented: the radiotherapy trajectory, family support and refuge in God and the importance of the multiprofessional team. The adverse reactions such as odynophagia, dysgeugia and weight loss were the ones that stood out the most, being causes of the social isolation of the participant, nonetheless the patient showed optimism and hope, despite the social isolation. Conclusion: The qualitative methodology allowed the whole trajectory of radiotherapy follow-up which made it possible to understand the treatment experience from the perspective of the participant. Despite the adverse reactions, no negative experience with radiotherapy was found. New studies using the qualitative methodology are suggested with groups presenting similar characteristics of the participant, thus providing a better understanding of the topic addressed, as well as the identification and adoption of strategies that aim at improving care and the quality of life of this population, as well.
\end{abstract}

Indexing terms: Head and neck neoplasms. Qualitative research. Radiotherapy.

\section{RESUMO}

Objetivo: Conhecer, compreender e descrever a experiência do tratamento oncológico radioterápico na perspectiva da mulher com câncer de boca. Métodos: Trata-se de um estudo qualitativo, exploratório, descritivo, com referencial teórico da antropologia médica e método do estudo de caso instrumental. A coleta de dados foi realizada no setor de oncologia de um hospital público universitário da região Sudeste do Brasil, estado de Minas Gerais e na residência da participante, durante o período de março a agosto de 2016 . O caso selecionado foi de uma paciente, gênero feminino, com diagnóstico de Carcinoma Espinocelular em cavidade oral, submetida à radioterapia. Foram realizadas eáudio-gravadas 5 entrevistas semiestruturadas e observação participante. Resultados: São apresentadas três unidades temáticas: a trajetória da radioterapia, redes de apoio e importância da equipe multiprofissional. Das reações adversas, a odinofagia, a disgeusia e a perda de peso foram as que mais se destacaram, sendo causas do isolamento social da participante. O sentido atribuído à radioterapia foi "otimismo e esperança, apesar do isolamento social". Conclusão: A metodologia qualitativa permitiu acompanhar toda a trajetória da radioterapia, o que oportunizou conhecer a experiência do tratamento na perspectiva da participante. Apesar das reações adversas, não foi verificada construção negativa da experiência com a radioterapia. Sugerimos novos

$\boldsymbol{\nabla v} \mathbf{v}$

1 Universidade Federal de Uberlândia, Faculdade de Medicina, Programa de Pós-graduação em Ciências da Saúde. Av. Pará, 1720, Umuarama, 38400-902, Uberlândia, MG, Brasil. Correspondência para / Correspondence to: DR MACEDO. E-mail: <dentistamacedo@hotmail.com>.

$\boldsymbol{\nabla} \mathbf{v} \mathbf{v}$

How to cite this article

Macedo DR, Anjos ACY. Experience of radiotherapy in head and neck. RGO, Rev Gaúch Odontol. 2019;67:e20190026. http://dx.doi. org/10.1590/1981-86372019000263529 
estudos utilizando a metodologia qualitativa, com grupos que tenham características semelhantes às da participante, proporcionando assim maior compreensão da temática abordada, além da identificação e adoção de estratégias que objetivem aprimoramento do atendimento e melhora da qualidade de vida desta população.

Termos de indexação: Neoplasias de cabeça e pescoço. Pesquisa qualitativa. Radioterapia.

\section{INTRODUCTION}

Oral cancer is considered a public health problem in several parts of the world, presenting an increasing incidence and high mortality rates. Although different types can be characterized, 95\% of the diagnosed cases are represented by Spinocellular Carcinoma (SCC). This disease, as well as the treatment and its side effects, cause countless consequences in the life of the sick people, whether in the social, economic and familiar environments [1]. In general, different treatment modalities are necessary; among them, radiotherapy (RT) is highlighted [2,3]. Several adverse reactions such as mucositis, xerostomia, dysgeusia, odynophagia and opportunistic infections (candidosis and herpes) can occur during the radiotherapy treatment of the head and neck region, which significantly affect patients' quality of life, resulting in not only physical difficulties such as phonation, chewing, swallowing and sucking, but also other emotional, social, family, professional and affective losses [4].Fear of pain and suffering can also trigger new concerns related to treatment outcome and its adverse reactions $[5,6]$. Preventive and curative dental treatment reduces the occurrence of oral complications during and after radiotherapy. It is also essential that the patient be informed about the paramount importance and necessity of participating in a preventive program based on dental control appointments and strict maintenance of the hygiene of the oral tissues, as well $[7,8]$.

The dentist is the most qualified professional to evaluate and apply preventive measures in patients undergoing radiotherapy in the head and neck region.

This manuscript focused on the female gender in which women present particularities, expectations and yearnings. Women in the eighteenth and nineteenth centuries did not have the right to vote or paid work and devoted themselves exclusively to the family. In contemporaneity they have been socially more evident and assumed their role with greater autonomy, freedom of expression, as well as emancipated their once suffocated ideas [9].

Gender issues relate to social relations and to the social roles played according to the sex of the individual.
Thus, while the sex of the person is linked to the biological aspect, the gender consists of a cultural construction [10].

Regarding Dentistry, most of the oral cancer studies use the quantitative methodology aiming at treating the physical side effects caused by RT. Therefore we have justified the relevance of the topic and have considered it opportune to develop a qualitative study, aiming at understanding the experience of radiotherapy oncological treatment, from the perspective of women suffering from oral cancer.

\section{METHODS}

The research project was previously submitted to the evaluation of the Ethics and Research Committee accredited to the National Health Council, being approved under the number of opinion 1,213,011.

This is an exploratory, descriptive study with a qualitative methodology. The Medical Anthropology was chosen for theoretical framework and the instrumental case study was used as methodology.

Medical Anthropology seeks to integrate health-disease processes with culture; considers health associated with the biological and the cultural aspects [11]. The understanding of the health-disease process as a sociocultural phenomenon evidences that experiences arising from this process are crossed by the socially constructed meanings [12].

The theoretical-methodological thinking of Medical Anthropology seeks to understand and interpret experience from the perspective of those who live it. It is necessary to interpret the subject's world of life, considering the process of cultural construction of the disease meanings and therapeutics, clarifying how they are incorporated in the language and actions of the social individuals who live the experience [13].

Among the different qualitative research methods compatible with the theoretical framework of Medical Anthropology, is the case study [14]. For Stake [15] the case study (CS) aims at making the case comprehensible 
and physical or social identity is presented as the only requirement. This author distinguishes three types of CS according to their purpose: intrinsic, instrumental and collective. In the instrumental CS, the interest in the case is that it may facilitate the understanding of something broader, since it can provide insight into a subject or yet the refinement of the theory.

This research was carried out in two diferent places, as follows: in the oncology wing of a public university hospital located in the Southeastern region of Brazil in the State of Minas Gerais, and in the residence of the study participant, living in another municipality, located $37 \mathrm{~km}$ away, from the city where she underwent her cancer treatment.

The selected case was a 69 year-old, Catholic white woman- named with the pseudonym Luci (chosen by the participant herself) and diagnosed with Spinocellular Carcinoma in oral cavity. She is the only child, housewife, at the time of the study she was retired; married for 52 years, mother of two children- a daughter and a son, the later had died thirteen years ago, a victim of urban violence. She lives in her own, masonry building house, with her husband and daughter- who is a single mother of a boy and a girl. Luci finished 9th grade of elementary school.

She reported having smoked for 40 years, but quit smoking twenty years ago; reported being a social drinker, drinking once a week; however, since the beginning of the radiotherapy, treatment has quit drinking. She reported monthly family income of three minimum wages. Among the reported health problems are: hypertension, scleroderma and dermatomyositis. She has not reported cases of cancer in her family.

In November of 2015, after a five-month investigation of a nodular lesion in the lower lip of the right side, found he once suffocated rself, she was diagnosed with Spinocellular Carcinoma in the oral cavity. The first proposal of treatment was surgery. About a month after the first diagnosis a cervical metastasis was found and another surgery was proposed followed by 36 sessions of RT which were carried out from May to July 2016.

She was invited to participate in the study, since she fulfilled the inclusion criteria as follows: being aware of the diagnosis and treatment proposed, being over 18 years old, with no deficit concerning understanding, willing to participate and previously signing the Free and Informed Consent Form (FICF).The first interaction between the dental researcher and the study participant was in the dental office of the oncology sector of the university hospital, during the pre-RT dental appointment. At this moment the invitation was made and presented: justification, objectives and form of participation in the research; later the Free and Informed Consent Form was signed. Data collection occurred from March to August 2016, a period corresponding to the treatment coverage. Five audio-tape semi-structured interviews and participant observation were carried out [14]. The interviews lasted for 25 minute, in average. They were performed at the dental office and at the participant's home. The average frequency between the meetings for the interviews was three weeks. The guiding questions developed for the interviews were:

"What do you know about RT treatment?"

"What is your expectation regarding radiotherapy?"

"Has RT been affecting / interfering with / harmed your life?"

"Can you tell me how you feel about the treatment?"

"Who is helping you during the treatment?"

"How is the help / support you have received?"

The observations focused on the posture adopted by the participant during the collection of statements, gestures, body signals, changes in tone of voice; that is, meaningful features for the subsequent interpretation of statements [14].

Data collection and analysis occurred simultaneously. Each interview was immediately transcribed and analyzed by the researcher. The analysis of the data collected was based on the proposal of Braun and Clarke [16], who propose the thematic and inductive analysis.

\section{RESULTS}

The data collection analysis showed three thematic units: "the radiotherapy trajectory", "family support" and "importance of the multiprofessional team".

\section{The radiotherapy trajectory}

After the diagnosis was confirmed and the surgical treatment of the lip and cervical metastasis were performed, RT was proposed in the head and neck region. Even without prior knowledge about this treatment, Luci demonstrated hope and optimism. 
(...) I hope it works out. I will undergo RT, I have to come every day. (1st interview)

"I never thought I'd need this one day... I wasn't even curious about it. (Luci justifies her lack of knowledge about RT- 3rd interview)

(...) I think I will end up by being cured, at least this is my perspective.. I am sure of this. (4th interview)

Mixed with this sense of hope concerning RT, Luci showed concern, especially regarding the possibility of reduced appetite and consequently weight loss.

"But I am afraid to lose my appetite because it is difficult for me to gain weight. But I am confidente that if I do it right, maybe it the illness will stop right there. (2nd interview)

After the 5th RT session, Luci began to feel uncomfortable in the oral cavity and this aroused Luci's feeling of fear regarding the progress of the treatment and a doubt was risen about the place of the radiotherapy, that is, where the Linear Accelerator would be operating.

(...) now I am afraid of that device (Linear Accelerator... I keep thinking of where it is burning now... (3rd interview).

"At the beginning it was very good, I felt nothing, no reaction. Then, when the reaction started, I think after the 5th session, I disliked it and was afraid (...) (3rd interview)

The following were the undesirable effects and adverse reactions mentioned by the participant during RT: odynophagia and dysgeusia, considered by Luci to be the worst side effects; to a lesser degree, also cited mucositis. These adverse reactions started after the second week of treatment, greatly affecting her feeding, she had to change the consistency of food, which increased her anxiety about the end of treatment.

"I am afraid of it (about RT), through the throat...it is harder to eat, harder to swallow (...) I can't wait to finish, maybe it gets better" (3rd intervie "(...) The food...

I am eating more pasty food.. more liquid.. it changed a lot(...) (3rd interview)

"(...) I feel it is the change of taste, because you do not sabor it (...) and there is no taste, ever... and these wounds [mucosite], these little things bother, but I still think it is not so bad as I see with the other patients who complain". (4th interview).
"(...) the taste of food you do not have, a little lack of appetite, and the worst is the lack of flavor, this for me is the worst! you do savor the food, you do not feel like eating and you do not even know what you're eating". (5th interview).

This feeding difficulty was also reported by Luci as a cause of her weakness and fatigue, changing her daily home tasks, as the following excerpts show:

"I think that it is my feeding, when you eat strong food, you become strong, so I feel that it is because of the lack of feeding" (4th interview)

(...) For example, on Mondays, Wednesdays and Fridays I used to wash the garage, now I don't anymore, I feel fatigue. I lie down and rest. This is what I do every day; today is Friday, it is the day I clean the garage, and my girl has washed it. I don't feel like doing it, my disposition has decreased a lot" (4th interview)

Weight loss played an important part in the trajectory of Luci's treatment- a consequence of the difficulty in feeding due to odynophagia and dysgeusia. The great loss of weight had as main repercussion her selfimage alteration and as a direct consequence, the social isolation. Luci reports that she stopped attending social events and places she liked and was used to go to; as we can observe in the following reports

(...) I don't want to..( Luci shows no disposition for social events and meeetings), I'd rather go when I gain more weight, the way I used to be, chubby. This is why I am away (...) This weight loss has put me down. (4th interview)

(...) I don't know whether it was for lack of appetite or savoring the food that I lost so much weight (...) The weight loss, this really hurts me" (5th interview) (...) No, no.. This is over! (about social life)...(...) I didn't go out anymore, did not go to church. For example, my grandson is going to be christened, I didn't want, I don't want to go, also because I am so thin... because I know people are going to ask me. these are the places I used to go, you know....so I really don't want to go, no, no (...) (3rd interview)

(...) I only go out to come here (to the hospital, where she undergoes radiotherapy), I don't feel like, first because I lost so much weight- people ask, you know- so I run away from this" (4th interview) 


\section{Family support}

Concerning to this phase of the treatment, on several occasions she reported that the support offered by her family was fundamental, especially from her husband and daughter. Her husband accompanied her at all RT appointments and her daughter helped with the house chores.

"My daughter and my husband give me strong support" (2nd interview)

"I used to wash the garage, Wednesday and Friday, but after I started the radio sessions, I feel weaker and I'd rather stay in bed and rest, then D (husband) and my daughter started cleaning the garage for me. (4th interview)

(...) he (husband) always helps me in the kitchen at lunch time, he always gives me a hand" (3rd interview)

Another source of support identified in this study was religiosity, demonstrated by the practice of prayers, in which Luci sought God's inner strengthening and hope for healing.

\section{Yeah, I pray a lot, (2nd interview)}

Honestly I think that God will help me, that I will get rid of this. so many people have this sickness and are healed (3rd interview)

An excerpt that corroborates the practice of prayers - as a source of healing power - is the moment in which she was positioned in the Linear Accelerator apparatus performing the RT:

"Right there (at the moment when she is at the Linear Accelerator), I pray, I ask for my healing, this is what happens when I am inside, I can't think of anything else, no I can't. (4th interview)

\section{Importance of multiprofessional team}

A fact of paramount importance in the trajectory of Luci's treatment was the performance of the hospital multiprofessional team, in charge of her treatment. The oncology service team consists of: dentist, doctor, nurse, nutritionist, social worker, physiotherapist, in addition to the reception staff and secretary. The good relationship generated confidence and encouraged the participant during the treatment:
"(...) the girls [receptionists at the hospital] are very polite here, and they have a way to deal with. Now regarding the doctor who is in charge of the radiotherapy he has been very attentive (...) "(3rd interview).

"Help! It gives you more strength, right! I raises you up, because it's not easy "[refers to the dedication of the professionals during her treatment] (3rd interview).

"Great! [refers to the professional staff of the hospital] beginning there from the concierge, until the radiotherapy; doctor, dentist and nurse, are very good people. So, I think that who is here, is graced by God, otherwise they wouldn't stay "(...) I think that here there are only people whom they are very sure they can help the patient, (4th interview).

\section{DISCUSSION}

In this study, the use of the qualitative method has good rapport between the researcher and the participant, allowing him to understand and describe, from the participant's perception, the meaning attributed to her trajectory of the radiotherapy treatment. Data based on the theoretical framework of Medical Anthropology made possible to identify the meaning attributed by Luci to the radiotherapy treatment: "optimism and hope, despite social isolation".

This work has highlighted women while focusing on particularities of the feminine universe with their expectations, longings and the change in their role and identity as well as their social and professional advancement which have promoted changes in the traditional family model. A woman who, in the past, had few options for choice, at present has been escaping biological and social determinism and thinking of herself as a citizen, or rather subject to her desire. Nowadays, more and more roles between men and women are no longer linked to sexual identity, but rather to the circumstances of different sociocultural contexts $[9,10]$.

In this scenario, considering the Brazilian woman's culture who also belongs to the low social class, it was found that the participant played several roles: housewife, wife, mother and grandmother. Her concerns were focused on household daily chores and care for her family members which she could not accomplish due to the RT. Luci did not fit into this new profile of contemporary women. 
The theme "The trajectory of radiotherapy" involves the pre and after - RT phase. Facing the unknown, concerning the RT in the head and neck region as well as not being able to previously interact with other irradiated patients, allowed Luci to build up positive mental perceptions related to her treatment and the illness. The lack of knowledge about what radiotherapy consequences may lead the patients into fear, anxiety and doubt about what impact RT will have on their lives and whether healing will be achieved. However Luci showed contrary behaviour, that is, her expectations were initially more positive and optimistic about the beginning of RT and she was confident that she would get cured. Her optimism while facing RT reflected a sociocultural context in which cultural influence can show world view, guiding kowledge, behaviour and practices concerning health.

Culture affects world view and guides knowledge, behaviour and practices facing health-illness and therapeutics [17]. Luci's optimism concerning RT has reflected socialcultural influence. In this pre-RT phase, associated with hope of cure with the treatment, Luci showed two strong concerns: reduced appetite and weight loss. According to Halkett et al. [6] and Sharloo et al. [18], RT may induce new fears, including concerns about the outcome of treatment and its side effects.

Odynophagia, dysgeusia and mucositis are among the adverse reactions of RT. Starting at the second week of treatment Luci complainted about undesirable effects. Radiation therapy is not selective once it does not differentiate normal cells from the malignant ones, which generates toxic effects for the body. Among these main acute effects are: mucositis, xerostomia, dysgeusia and odynophagia [19]. This confirms Luci's reports and mucositis brought less damage and discomfort to the participant. Although xerostomia was one of the adverse reactions to radiotherapy, Luci did not report its occurrence during treatment.

Along with these adverse effects Luci reported feelings of anxiety and fear: '... after the 5th session, I was already a bit scared about it and afraid ..." which, according to Horney et al. [20] in the period of radiotherapy, the head and neck cancer patient experiences a high level of distress and suffering and the anxiety increases from the second week of the radiotherapy treatment when the side effects begin.

Luci's life quality was harmed due to RT side affects; especially related to odynophagia and dysgeusia, which caused her difficulties in eating, due to lack of taste and loss of appetite. As a result of poor diet, there was weight loss and self-image impairment which triggered her social isolation.

Eating problems should be seen as a complex issue, since it represents a social activity which promotes social interaction and identity. Weight loss can have a negative impact on self-image and quality of life [21]. The suffering caused by the negative self-image is not only in the physical discomfort, but mainly in the restrictions in her life, the social isolation and the feeling of being a burden by the loss of autonomy [22], a experienced reported by Luci.

The body is not only biological, it is composed by culture and it is a social product, since it brings relations with other bodies in society. It is the vehicle of being in the world, which expresses the feelings and perceptions in a situation of illness, pain and suffering, revealing that one has a body and one is a body [23].

Larsson et al. [24] study tried to understand the experience of eight (8) head and neck cancer patients' eating problems, their consequences in daily life and strategies to deal with these problems during radiotherapy. Using deep interviews, the research concluded that radiotherapy caused serious damage to the patient's diet, mainly due to chewing and swallowing pain, loss of taste and appetite, and these eating problems also cause loss of patient's sociability; feelings of hope and uncertainty mingled during and after treatment. These results and conclusions corroborate the experience of Luci.

Another study by Mcquestion et al. [25] I aimed at understanding the experience of seventeen [26] head and neck cancer patients in relation to eating disorders caused by radiotherapy treatment, also corroborates Luci's experience in which the participants felt distressed by the food problems that have arisen, among them, the loss of weight which determined a negative impact on body image, pain in swallowing and alteration of the palate. In addition to these physical problems, according to the participants' reports, the emotional suffering associated with what they could not eat and the loss of social contact with family and friends were also highlighted.

Concerning support, the family was the great support for Luci; for Ottosson et al. [27], family support is very important during treatment and recovery providing emotional support as well as family adaptation to the 
patient's new routine and needs. This situation clearly occurred, in relation to the needs presented by Luci, especially when referring to the support and care received from her husband.

Family can be considered as a protective source of cultural knowledge that establishes and normalizes practices or actions to deal with the dramatic situations of life [28].

The participant mentioned believing in God and used prayer as a resource for inner strengthening. Most people, when they are at the forefront of different situations of suffering such as fear and pain, seek for religious practices in the hope of spiritual and emotional strength [29] .

Geertz [13] states that religiosity, through symbols, provides explanations for human experiences. The quest for God's help refers to the symbolism of a supreme power that will help in times of distress and suffering. Religion, as support in difficult moments, is a sociocultural conception apprehended in the family context and the social group where the person is inserted.

Regarding "importance of the multiprofessional team", the participant reported feeling satisfied with the care received; did not present any complaints, instead, she praised the team and demonstrated, that this good relationship has improved her confidence and provided more courage to face the treatment. This confidence demonstrated by Luci corroborates with the study of Egestad [30] that aimed at describing and understanding how the meetings with the radiotherapist have affected the experience of head and neck cancer patients during radiotherapy. Interviews were conducted with the participation of eleven participants, identifying that the meetings with the radiotherapist provided positive and significant changes on the participants' experiences. When the radiotherapist demonstrated professionalism, competence and assumed responsibility for treatment, it reduced patients' anxiety and created a sense of confidence; when the professional showed incompetence, the anxiety of the participants increased.

The dedication of the health professional to his patient is of paramount importance for a successful treatment. The patient's quality of life should be taken into account in the clinical practice of the professional involved in cancer care, prioritizing humanized care, attentive and comprehensive listening, as well as educational and guidance work to the patient and family, throughout the treatment.

It is important to emphasize that most oncology services, especially those that provide free care to cancer patients, through the Unified Health System (SUS), face many difficulties in offering care that is considered humanized due to several factors, among which downgraded professionals such as physician, nurse and mainly dentist associated to the increasing demand of patients and attendance is focused on the treatment of only physical signs and symptoms. The shortage of time impairs these professionals to focus and deepen the patient's sociocultural, emotional and psychological issues.

The assistance provided by Dentistry has been based on the resolution of physical problems, although in oncology, it is difficult to find professionals who are involved with the patient's experience. Therefore developing this research was of great value.

The trans-radiotherapy phase was marked by antagonistic feelings, that is, at the same time that Luci mentioned hope of healing, she was afraid of side effects, mainly odynophagia and dysgeusia.

Although the study involved only one patient and it could be considered a limitation in the quantitative perspective, it fits the social, demographic and clinical characteristics of patients attended by public oncological hospital institutions; thus, the results can be extended to other groups with similar characteristics, which characterizes the instrumental case study. According to Stake [15], the case may be a person, a specific group of people, an organization, or a particular event. Thus, the case can be used once it as an example of a woman, or even because the case is interesting in itself, which confirms the relevance of the case of Luci, the participant selected for this research.

\section{CONCLUSION}

The qualitative methodology provided interactiion between the researcher and the participant, allowing the observation as well as understanding participant's daily life issues which could interfere or influence the treatment commitment and / or the expected results that would often go unnoticed by the researcher and by other professionals who provided assistance. These aspects were relevant to the understanding of anxieties or even to clarify 
participants' behaviors during the treatment, essential for greater humanization and uniqueness in cancer patient care. It was concluded that the participant did not present a negative perception of her experience with radiotherapy - since negative perception contributes to reproduce the stigma of cancer and its treatments. Other studies which include the relatives of the patient are necessary and the use the qualitative methodology to deeply explore the aspects of the subject addressed, thus increasing the understanding of the experience related to radiotherapy and adopting strategies that aim at improving the service offered to groups with similar characteristics, and consequently improved quality of life.

\section{Collaborators}

DR MACEDO was in charge of writing and data collection of the manuscript. ACY ANJOS was in charge of writing, data collection and article review.

\section{REFERENCES}

1. Fernandes GM, Bergmann A, Oliveira JF de. Análise epidemiológica de população com câncer de cabeça e pescoço: influência sobre as complicações pós operatórias. Rev Bras Cir Cabeça Pescoço. 2013;42(3):140-9.

2. Da Silva SD, Ferlito A, Takes RP, Brakenhoff RH, Valentin MD, Woolgar JA, et al. Advances and applications of oral cancer basic research. Oral Oncol. 2011;47(9):783-91. http://dx.doi. org/10.1016/j.oraloncology.2011.07.004

3. Rossi VC, Fernandes FL, Ferreira MAA, Bento LR, Pereira PSG, Chone CT. Larynx cancer: quality of life and voice after treatment. Braz J Otorhinolaryngol. 2014;80(5):403-8. http:// dx.doi.org/10.1016/j.bjorl.2014.07.005

4. Sharma A, Madan R, Kumar R, Sagar P, Kamal VK, Thakar $A$, et al. Compliance to Therapy-Elderly Head and Neck Carcinoma Patients. Can Geriatr J. 2014;17(3):83. http://dx.doi. org/10.5770/cgj.17.101

5. Martino R, Ringash J. Evaluation of quality of life and organ function in head and neck squamous cell carcinoma. Hematol Oncol Clin North Am. 2008;22(6):1239-1256. http://dx.doi. org/10.1016/j.hoc.2008.08.011

6. Halkett GKB, Cox J, Anderson C, Heard R. Establishing research priorities for Australian radiation therapists: what patient care priorities need to be addressed? Eur J Cancer Care. 2012;21(1):31-40. http://dx.doi.org/10.1111/j.1365-235 4.2011.01276.x

7. Silva L, Barbosa B, Matos M. Efeitos agudos do tratamento de radioterapia em doentes com carcinoma de cabeça e pescoço: IMRT vs RapidArc. 2014 [citado 31 maio 2016]. Disponível em: <http://recil.grupolusofona.pt/handle/10437/4600>.
8. Semple CJ, Dunwoody L, George Kernohan W, McCaughan E, Sullivan K. Changes and challenges to patients' lifestyle patterns following treatment for head and neck cancer. J Adv Nurs. 2008;63(1):85-93. http://dx.doi.org/10.1111/j.13652648.2008.04698.x

9. Borsa JC, Feil CF. O papel da mulher no contexto familiar: uma breve reflexão. O Portal Psicólogos. 2008;185:1-12.

10. Cunha TRA, Alves AES. Educação e violência nas relações de gênero: reflexos na família, no casamento e na mulher. Em Aberto. 2015;27(92).

11. Langdon EJ. Cultura e processos de saúde e doença. In: Oliveira JM, Organ AN. Seminário sobre cultura saúde e doença. Londrina: Fiocruz; 2003. p. 91-105.

12. Costa G, Gualda DM. Antropologia, etnografia e narrativa: caminhos que se cruzam na compreensão do processo saúdedoença. Hist Cienc Saude-Manguinhos. 2010;17(4):925-937.

13. Geertz C. O impacto do conceito de cultura sobre o conceito de homem. In: Geertz C. Interpretação cultural. Rio de Janeiro: LTC; 1989. p. 25-40.

14. Pope C, Mays N. Pesquisa qualitativa na atenção à saúde. São Paulo: Artmed; 2009.

15. Stake R. Case Studies. In: Denzin NK, Lincoln YS. (ed.). Handbook of qualitative research. London: Sage; 2000.

16. Braun V, Clarke V. Using thematic analysis in psychology. Qual Res Psychol. 2006;3(2):77-101.

17. Langdon EJ, Wiik FB. Anthropology, health and illness: an introduction to the concept of culture applied to the health sciences. Rev Lat Am Enfermagem. 2010;18(3):459-466. http://dx.doi.org/10.1590/S0104-11692010000300023

18. Scharloo M, Baatenburg de Jong RJ, Langeveld TPM, van Velzen-Verkaik E, Doorn-Op den Akker MM, Kaptein AA. Illness cognitions in head and neck squamous cell carcinoma: predicting quality of life outcome. Support Care Cancer. 2010;18(9):1137-45. http://dx.doi.org/10.1007/s00520-0090728-X

19. Jawad $H$, Hodson NA, Nixon PJ. A review of dental treatment of head and neck cancer patients, before, during and after radiotherapy: part 1. Br Dent J. 2015;218(2):65-68. http:// dx.doi.org/10.1038/sj.bdj.2015.28

20. Horney DJ, Smith HE, McGurk M, Weinman J, Herold J, Altman $\mathrm{K}$, et al. Associations between quality of life, coping styles, optimism, and anxiety and depression in pretreatment patients with head and neck cancer. Head Neck. 2011;33(1):65-71.

21. Semple CJ, Dunwoody L, George Kernohan W, McCaughan E, Sullivan K. Changes and challenges to patients' lifestyle patterns following treatment for head and neck cancer. J Adv Nurs. 2008;63(1):85-93. http://dx.doi.org/10.1111/j.1365-2648. 2008.04698.x

22. Helman CG. Cultura, saúde e doença. 4a ed. Porto Alegre: Artmed; 2003.

23. Adam P, Herzlich C. Sociologia da doença e da medicina. Bauru: EDUSC; 2001.

24. Larsson M, Hedelin B, Athlin E. Lived experiences of eating problems for patients with head and neck cancer during radiotherapy. J Clin Nurs. 2003;12(4):562-70. https://doi. org/10.1046/j.1365-2702.2003.00751.x 
25. McQuestion M, Fitch M, Howell D. The changed meaning of food: Physical, social and emotional loss for patients having received radiation treatment for head and neck cancer. Eur J Oncol Nurs Off J Eur Oncol Nurs Soc. 2011;15(2):145-51. https://doi.org/10.1016/j.ejon.2010.07.006

26. Haisfield-Wolfe ME, McGuire DB, Krumm S. Perspectives on coping among patients with head and neck cancer receiving radiation. Oncol Nurs Forum. 2012;39(3):E249-57. https:// doi.org/10.1188/12.ONF.E249-E257

27. Ottosson S, Laurell G, Olsson C. The experience of food, eating and meals following radiotherapy for head and neck cancer: a qualitative study. J Clin Nurs. 2013;22(7-8):1034-43. https://doi.org/10.1111/jocn.12151
28. Elsen I, Marcon SS, Silva MRS da. O viver em família e sua interface com a saúde e a doença. Maringá; Eduem; 2002.

29. Ferreira MBLS, Vieira MM. O lugar da religião no tratamento do paciente oncológico. Ces Rev. 2014;28(1):119-130.

30. Egestad $\mathrm{H}$. How does the radiation therapist affect the cancer patients' experience of the radiation treatment? Eur J Cancer Care (Engl). 2013;22(5):580-8. https://doi.org/10.1111/ecc. 12062

Received on: 8/4/2018 Final version resubmitted on: 30/9/2018

Approved on: 2/11/2018 